\title{
Assessing the Economic Impact of Oil and Gas Production on Ghana's Economy
}

\author{
Benjamin Debrah \\ Department of Agricultural Economics, Market and Rural Development, Faculty of Agriculture, University of \\ Belgrade \\ Nemnjina 6, 11080 Belgrade-Zemun, Serbia
}

\begin{abstract}
Since the discovery of oil in the offshore coast of Ghana in 2007, the nation has had increased expectations on possible accelerated economic growth and development. This oil and gas if managed well has the possibility to transform a structurally week economy into a self-sustain economy. Likewise, if not well managed can lead to social, economic and political instability as it can be seen in some oil rich countries where their economies are characterized by corruption, poverty and conflict.The aim of this study was to find out the economic impact of oil and gas production on Ghana's economy. The research employed the analysis of secondary data from the World Development Indicators, World Bank. Data were processed and analysed using SPSS statistical software. Simple linear regression analysis was performed to analyse the impact of oil rents on Ghana's economy.The study revealed that revenue accruing from oil rents affect GDP growth positively and therefore considered impactful on Ghana's economy since it represents net addition to capital stock. Averagely, Ghana has been experiencing GDP growth of $6.1 \%$ per annum with average contribution of oil rent being $1.8 \%$ per annum (20002018). The regression analysis shows that a percentage increase in oil rents will lead to a corresponding increase in GDP growth by $0.788 \%$ per annum, which is approximately $1 \%$ per annum. It was also revealed that there has been a paradigm shift in Ghana's economy from an agrarian to a more industrialised and service oriented economy with gradual increase in oil discoveries since 2011.
\end{abstract}

Keywords: Oil and Gas production; Economy; Capital Accumulation; Oil rents; Ghana

DOI: $10.7176 / J E S D / 12-14-08$

Publication date:July $31^{\text {st }} 2021$

\subsection{INTRODUCTION}

It is irrefutable that oil, with is popularly called black gold, fuels the global economy. Oil converted into petrol and diesel fuels our various modes of transportation that allows for the movement of goods and people around the universe. Due to the massive financial resources that can accrue from this industry, the discovery of oil in any location, particularly developing countries, is welcomed with great hope. Such was the situation in the golden jubilee year of Ghana's independence when oil was discovered in commercial quantities in the Western Region of Ghana. By the year 2011, Jubilee fields was estimated to produce 120,000 barrels of oil per day and the revenue from the oil and gas exploration was estimated to reach a heap sum of US\$20 billion from 2012 to 2030 (Gary, 2009). Extractive activities, including oil exploration can have a positive effect on development by creating jobs, motivating businesses and providing important infrastructure such as roads, electricity, education and health for rural communities (Darkwah, 2010).

Due to the huge financial resources that can accrue from the oil and gas industry, its role in a country's economic development cannot be taken for granted. Oil does not only serve as a major foreign exchange earner for a nation but also creates employment for people. On February 19, 2009, International Finance Corporation (IFC) Board of Directors authorised Ghana to enter into investment agreements to support the development of Ghana's Jubilee field, an offshore oil and gas project that will help to diversify Ghana's economy and satisfy its energy needs (Boohene and Peprah, 2011).

The announcement of the oil discovery generated a huge public debate about: How much money will accrue from the oil production? How will government manage the revenue? What should the revenue from the hydrocarbon resources be used for? Will Ghana be able to avoid the so called 'resource curse' as with other resource rich countries? Moreover, several consultations were done prior to the production of oil. Some of these included regional consultations on the management of the petroleum revenue, development of a local content and participation policy, petroleum revenue management bill which was subsequently passed into a law, the petroleum exploration and production bill among others (FES Ghana, 2011).

Ghana, like other developing countries can effectively manage its oil revenue and use the proceeds as an engine of growth for accelerated development through sustainable planning from upstream, midstream and downstream activities. Major problems for Ghana would be how to develop the oil and gas industry with optimal local content and participation, how to provide security for the industry and the overall management of potential revenue from oil and gas production. By comparative analysis, Ghana can do better in areas many countries have failed in relation to the management of exploration and exploitation of its crude oil. Facing the fact that crude oil 
and gas as natural resources are exhaustive and temporary, the broad objective of the country should be to effectively use revenues accrued from oil production in order to achieve a diversified and stable economic growth. The set-up of the national petroleum regulatory authority responsible for the regulation of all petroleum activities and the creation of a future generation fund and stabilization fund to ensure transparency and equity of benefit for both present and future generations are good initiatives. To obtain full potentials from the oil industry, the regulatory initiatives should be assisted by building a supportive human resource capacity, technological transfer, strong regulatory and legal frameworks (UK Essays, 2018).

\subsection{LITERATURE REVIEW}

\subsection{Oil and Gas production and Ghana's Economy}

Ghana discovered oil in commercial quantities in June, 2007, and became Africa's newest oil producer in 2007. Meanwhile, the government of Ghana remains confident that the country will be able to avoid some of the problems related to some oil-rich countries, such as increased corruption, increased debt, Dutch Disease, competition for resources and conflict over resource revenues. On the other hand, many local and international observers remain concerned that Ghana's enviable track record of economic, social and democratic development over the last 20 years may be wiped away by the challenges posed by the oil discovery. The International Monetary Fund expected Ghana's economy to grow by 13 percent in 2011, as a result of the new oil discovered. The government is expected to receive billions of dollars in new revenues over the next decade, but how these new revenues are managed will be vital to whether Ghana continues on the right path.

After more than a decade of sustained international focus on addressing the "resource curse" and after the failed experiment in Chad designed to turn oil revenues into poverty reduction, many have put their hopes in Ghana. Countries to the west of Ghana, such as Sierra Leone and Liberia, are now actively pursuing oil development and Ghana may have positive as well as negative lessons to share with its neighbors.

The beginning of oil production was preceded by three and a half years of intense work by the consortium partners and with an investment of over $\$ 3.5$ billion. The commercial partners on the Jubilee filed are Tullow Oil Company (34.70\%), Anadarko Petroleum Corporation (23.49\%), Kosmos Energy (23.49\%), the Ghana National Petroleum Corporation - GNPC (13.75\%), Sabre Oil and Gas (2.81\%) and the E.O. Group (1.75\%). The Jubilee Field started producing 70, 000 barrels per day beginning December, 2010 and estimates were that by June, 2011, Ghana will be producing approximately 120,000 barrels of oil per day. Production technology relies on the use of undersea wells to gather oil to a Floating Production Storage and Offloading vessel (FPSO) $60 \mathrm{~km}$ offshore and it is then off-loaded into shuttle vessels for export to the international market. The Jubilee field contains 600 million barrels of proven oil reserves and has a potential for over 1.5 billion barrels of oil. The production rate is expected to provide more than \$400 million to the government's 2011 budget and around \$1 billion per year to the country in the early years of producing oil. Tweneboa and Enyenra fields were projected to hold around 400 million barrels of oil and that initial plans call for a second FPSO in Ghanaian waters designed to handle 75,000 to 125,000 barrels per day from these fields (Civil Society Platform on Oil and Gas - Ghana, 2011). The impact of oil on the Ghanaian economy and society will depend on the policies instituted to manage the use of the oil revenue (IFC, 2018).

The expectation that petroleum would help Ghana end its fiscal problem has not yet been materialised. While the oil share in total domestic revenues has been rising, domestic revenues as a proportion of GDP have remained stagnant. This result suggests, then, that oil earnings may be substituting for other forms of revenues. Oil now threatening gold, as it was fast becoming the dominant single source of export earnings for Ghana, until the recent drop in its world price. Petroleum has now also become the dominant industrial component in mining and quarrying, representing nearly 90 percent of the sub-sector. Indeed, petroleum primarily explains why the industrial sector has overtaken agriculture since 2011. With oil exports exceeding oil imports since 2013, Ghana now seems to have become a net oil-exporting country. However, the country is not yet an oil-dependent economy and is certainly far from her oil-dependent neighbour Nigeria, where over 90 percent of export earnings and approximately 80 per cent of its revenues are derived from oil. Ghana's oil contributes a share of about 30 percent of export earnings and 12 percent of its revenue. Thus, Ghana has time to adjust accordingly in order to avoid the oil curse (Fosu, 2017). Also, investing petroleum proceeds in the non-oil sector and expansion of the export base are viable options for utilizing petroleum revenues (Acquah-Andoh, Gyeyir, Aanye and Ifelebuegu, 2018).

\subsection{Norwegian Oil and Gas Industry}

The period of Norway's petroleum started more than 50 years ago. The first fields that were developed were in the North Sea and since then the industry has gradually expanded northwards into the Norwegian Sea and the Barents Sea (Norwegian Petroleum Directorate, 2020). In the late 1950s, very few people believed that the Norwegian continental shelf (NCS) might contain rich oil and gas deposits (Government.no, 2020).

The Norwegian Government proclaimed sovereignty over the Norwegian continental shelf in May 1963 and 
new act was adopted establishing that any natural resources on the shelf belongs to the Norwegian state, and that only the King has the authority to award licences for exploration and production. The Norwegian state's participating interest was divided in two: one part linked to Statoil and one to the State's Direct Financial Interest (SDFI) in the petroleum industry.

During the beginning of the $21^{\text {st }}$ century, the Norwegian shelf was opened up to more types of companies as a way of ensuring sound resource management. The big international oil companies that were already established on the shelf were combined by other types of companies that could perceive different kinds of commercial opportunities in Norway's petroleum resources (Norwegian Petroleum Directorate, 2020).

Since production started on the Norwegian continental shelf in the early 1970s, petroleum activities have contributed to more than 15,700 billion in current NOK (Norwegian krone) to Norway's GDP. And does not include related service and supply industries. So far, only about $47 \%$ of the estimated recoverable resources on the Norwegian shelf have been produced and sold (Government.no, 2020).

\subsection{Nigerian Oil and Gas Industry}

Crude oil exploration and production in Nigeria began under British colonialism. This was in spite of the fact that, the industrial sector was one aspect of the Nigerian economy the British were most reluctant to develop (Okorobia and Olali, 2018)

Oil was discovered in Nigeria in 1956 at Oloibiri in the Niger Delta after half a century of exploration. Nigeria joined oil producing countries in 1958 when its first oil field started producing 5,100 barrels per day. In 1970, the end of the Biafran war coincided with the rise in the world oil price, and Nigeria was able to reap instant riches from its oil production. Nigeria joined the Organization of Petroleum Exporting Countries (OPEC) in 1971 and established the Nigerian National Petroleum Company (NNPC) in 1977, which is state owned and controlled company. By the late sixties and early seventies, Nigeria had achieved a production level of over 2 million barrels of crude oil per day. Even though, production figures dropped in the eighties, 2004 saw a total rejuvenation of oil production to a level of 2.5 million barrels per day. Petroleum production and export play a major role in Nigeria's economy and account for about $90 \%$ of its gross earnings. This dominant role has overshadowed agriculture, the traditional mainstream of the economy, from the early fifties to sixties (NNPC, 2020).

\subsection{Investment in Ghana's Economy}

Foreign Direct Investment (FDI) is a strategy aimed to encourage existing investors to reinvest in Ghana's economy. Reinvestments will encourage new foreign investors to enter Ghana' economy. New investments by existing foreign investors in mining, agribusiness, telecommunications and financial services are expected to contribute to the increase of employment, exports, foreign exchange receipts, tax revenues and economic growth. Ghana provides a variety of incentives for foreign investors which include tax holidays, capital allowances, locational incentives, customs duty exemptions and other inducements. These are specified in the relevant statutes and applied fairly with relevant legislations (UNCTAD, 2003).

As a result of much effort done by the government to attract potential investors into the country, inflow of foreign direct investment in Ghana has grown rapidly since 2006. Investors enjoy reasonable conditions and rights for investing in Ghana. Greater Accra region received most of the registered projects compared to the other regions in Ghana. The rate at which investment was allocated to service sector has changed and much attention being focused on the manufacturing sector (Yeboah, 2018).

Moreover, the accessibility of oil and its capacity to attract foreign investment does not guarantee economic development. However, the establishment of appropriate institutions, mechanisms and policies would ensure efficient use of oil revenue to sustain economic growth. Oil production could attract foreign direct investment and contribute to the economic development of Ghana only with requirement that appropriate oil revenue management policies are implemented (Dah and Khadijah, 2010).

\subsection{Government Policies and Oil and Gas Resource Management}

Government policies and oil and gas resource management fall into two main regulatory bodies: Legal and Regulatory Frameworks and Petroleum Sector Agencies:

\subsubsection{Legal and Regulatory Frameworks}

According to the Law Reviews (2020), under the Constitution of Ghana, all untapped natural resources including oil and gas resources are vested in the President of Ghana for and on behalf of the people of Ghana. Therefore, the right to explore and develop such resources is subject to agreement or license granted by the government (acting through the Ministry of Energy) and approved by Parliament. These legal and regulatory frameworks include: The Petroleum Commission Act, 2011 (Act 821); Petroleum (Local Content and Local Participation) Regulations, 2013 (Li 2204); The Petroleum Revenue Management Act, 2011 (Act 815); Petroleum (Exploration and Production) Regulations, 2016 (Li 2246) and Environmental Protection Agency (EPA) Act 1994 (Act 490). 


\subsubsection{Petroleum Sector Agencies}

A presentation made by Shamo (2013), on the petroleum sector agencies, outlined the following major responsibilities of various agencies within Ghana's petroleum industry. The key responsibilities are as follow:

Table 1: Petroleum Sector Agencies and their Main Responsibilities.

\begin{tabular}{|l|l|}
\hline Agencies & Main Responsibilities \\
\hline Ministry of Energy \& Petroleum & Provide policy guidelines and supervise sub-sectors \\
\hline Petroleum Commission & Regulate upstream and midstream activities \\
\hline National Petroleum Authority & Regulate downstream activities \\
\hline Ghana National Petroleum Corporation & Hydrocarbon exploration, development and production \\
\hline Tema Oil Refinery & Crude oil refinery and sales of petroleum products \\
\hline $\begin{array}{l}\text { Bulk Oil Storage and Transportation Company } \\
\text { (BOST) }\end{array}$ & Bulk petroleum products storage and transportation \\
\hline Ghana National Gas Company & $\begin{array}{l}\text { Natural gas processing and sale of products from gas } \\
\text { processing }\end{array}$ \\
\hline Ghana Cylinder Manufacturing Company & LPG cylinder manufacturing \\
\hline Bulk Oil Traders & Petroleum products importation and sale \\
\hline Oil Marketing Companies & Petroleum products distribution \\
\hline International Oil Companies & Hydrocarbon exploration, development and production \\
\hline Environmental Protection Agency & Regulates environmental issues in Oil and Gas \\
\hline
\end{tabular}

Shamo (2013). Ministry of Energy and Petroleum.

\subsection{The Concept of Resource Curse}

There is a proposition that an abundance of a natural resource is associated with declining national standards of living rather than prosperity. This is as a result of dependence on a single natural resource for export, for instance, oil or gas. It was first realised that resources might be a curse in the 1990s, when it was noted that oil-rich countries were not growing as quickly as others. Going forward, economic analysis found strong support for the idea, although it is still debated. Empirical or proven confirmation usually takes the form of relationships between resource availability and national economic performance. The economic causes are that dependence on one natural resource overshadows investment in manufacturing and agriculture, making them less competitive, while making the national economy over-reliant on a single commodity whose value in world markets might be volatile (Oxford Reference, 2021).

There are various reasons put forward to explain this resource curse, such as corruption, increase in exchange rate, foreign ownership and conflict. Nigeria, Zambia, Sierra Leone, Angola, Saudi Arabia and Venezuela are examples of resource-rich countries with relatively poor rates of economic growth. Resource-poor countries, such as Korea, Taiwan, Hong Kong, Japan and Singapore, on the contrary, have experienced better rates of economic growth. Furthermore, natural resources tend to be owned by firms with significant degrees of monopoly. In often times, these firms happen to be global multinationals seeking rent in other countries. This means that the profits from selling natural resources are taken primarily by a small percentage of wealthy foreign shareholders. It also means that profits flow back to the country of the multinational and do not directly benefit the developing economy (Economics help, 2021). This monopolistic ownership can equally raise a big debate concerning the arguments teased out by Lucas, Robert E. (1990) in his reviewed paper titled "Why Doesn't Capital Flow from Rich to Poor Countries?" 


\subsection{MATERIALS AND METHODS}

3.1 Study Area: Profile of Ghana's Oil and Gas Industry

Figure 1: Oil and Gas reserves in Ghana

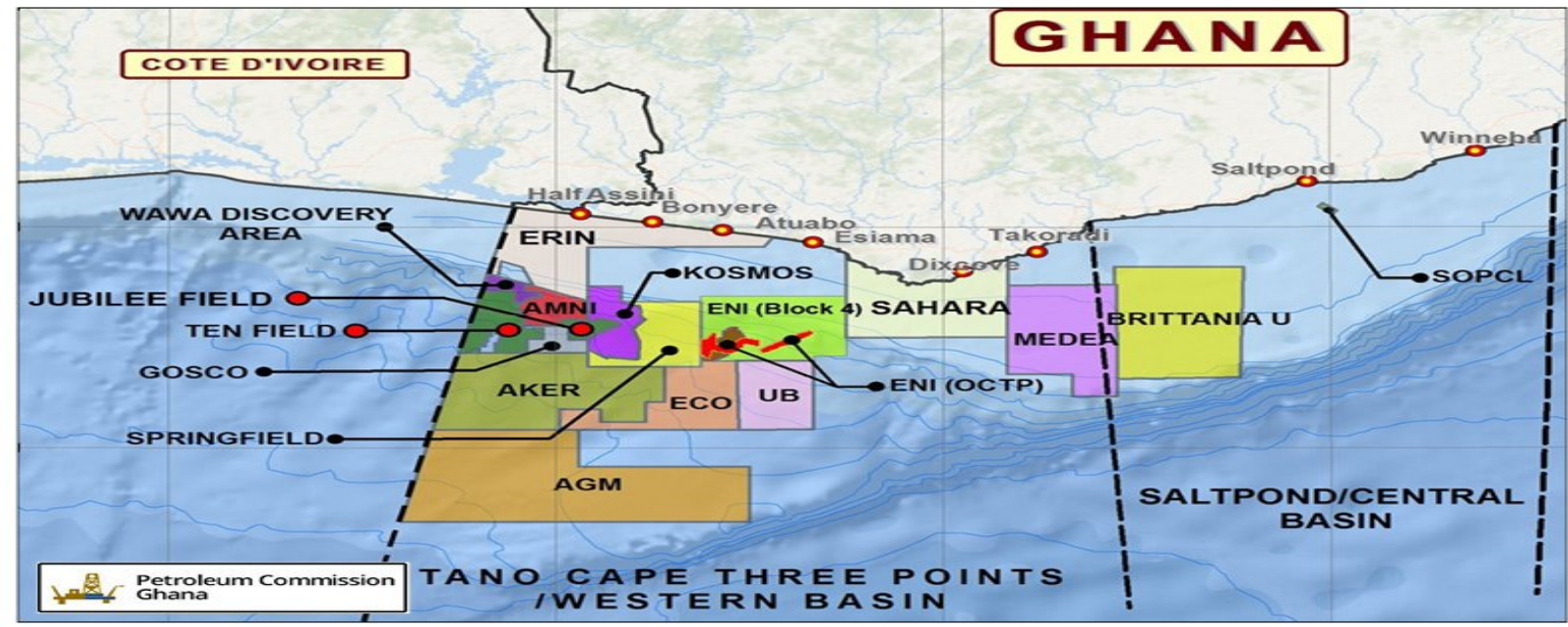

Source:https://www.geoexpro.com/articles/2019/12/first-independent-hydrocarbon-discovery-in-ghana Downloaded on $29^{\text {th }}$ January, 2021, at 2:30PM.

\subsection{Sources and Types of Data}

The research employed the analysis of secondary data from the World Bank's data bank. In order to determine the actual impact and true state of Ghana's oil and gas sector, secondary data on oil rents and gross domestic product (GDP) growth of Ghana, Norway and Nigeria were purposefully selected for analysis, since Norway is recognize as one of the successful oil-rich countries in the world and Nigeria being otherwise. Additionally, data on Ghana's Agricultural share of GDP, Service sector share of GDP and Industrial share of GDP were also collected from the World Bank's data bank for further analyses.

\subsection{Data Analysis}

The data were processed and analysed using SPSS statistical software. Microsoft Excel was also used to calculate figures and other statistical analysis. Tables and figures were used to present the data. Measures of central tendency and measures of dispersion were also used in the analyses. Simple linear regression analysis was performed to assess the impact of oil rent on Ghana's economy, with respect to GDP growth.

\subsection{Contribution of Oil Rents to GDP Growth Model}

Estimated Regression Equation: Oil rents - GDP growth Model

An empirical analysis of the contribution of Oil rents to GDP growth was formulated with simple linear regression equation as follow:
$\mathrm{Y}=\mathrm{b}_{0}+\mathrm{b}_{1} \mathrm{X}_{1}+\varepsilon$
.............
eqn. (1)
$\hat{\mathrm{Y}}=\mathrm{b}_{0}+\mathrm{b}_{1} \mathrm{X}_{1}$
eqn. (2) (Estimated Equation)

Where: $\quad \hat{Y}=$ economic growth of GDP (2000 to 2018)

$\mathrm{b}_{0}=$ the intercept $/$ the $\mathrm{Y}$ intercept

$\mathrm{b}_{1}=$ coefficient of oil rent share of GDP

$\mathrm{X}_{1}=$ oil rent share of GDP (2000 to 2018)

Misini (2017), also used simple linear regression analysis as a more suitable and sophisticated model to compare unemployment and nominal GDP in Kosovo.

\subsection{RESEARCH RESULTS AND DISCUSSIONS}

\subsection{Ghana's annual Oil Rents as a percentage of GDP}

World Bank (2020), defined oil rents as the difference between the value of crude oil production at world prices and total costs of production. In some countries, earnings from natural resources, especially from fossil fuels and minerals, account for a sizable share of GDP, and much of these earnings come in the form of economic rents, which signifies revenues above the cost of extracting the resources.

With reference to (figure 5) below, there is an indication of general fluctuations in the contribution of oil rents to the Gross Domestic Product (GDP) of Ghana, with the highest record in 2011 and the least in 2009. Although, there has been fluctuations in oil rents share of GDP over the years, there has also been a significant increase since 2011. The appreciations in oil rent since 2011 could be linked to the significant increase in crude 
oil production since the discovery of oil in large quantities in the year 2007 and good managerial practices.

Figure 2: Ghana's annual Oil Rents as a percentage of GDP (2000-2018)

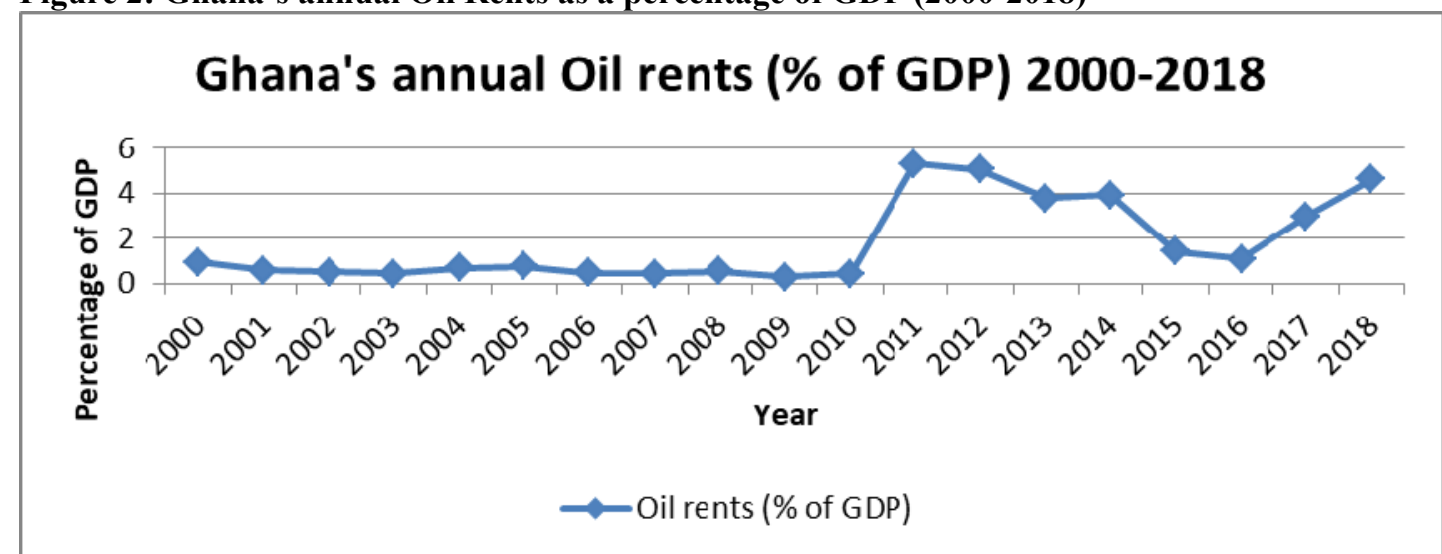

Source: Author's computation from World Development Indicators. World Bank (2020). Available: https://databank.worldbank.org/source/world-development-indicators

The occurrence in (figure 5) above confirms with what Civil Society Platform on Oil and Gas, Ghana (2011) said that the beginning of oil production was preceded by three and a half years of intense work by the consortium partners and with an investment of over $\$ 3.5$ billion. They further asserted that Jubilee Field started producing 70, 000 barrels per day beginning December, 2010 and estimates were that by June, 2011, Ghana will be producing approximately 120,000 barrels of oil per day. The production rate is therefore expected to provide more than $\$ 400$ million to the government's 2011 budget and around $\$ 1$ billion per year to the country in the early years of producing oil.

4.2 Ghana's Real GDP and GDP Growth (annual percentage)

The (figure 6) below, represents Ghana's real GDP in billions of US dollars and its growth in annual percentage. Figure 3: Ghana's Real GDP and GDP Growth (annual \%)

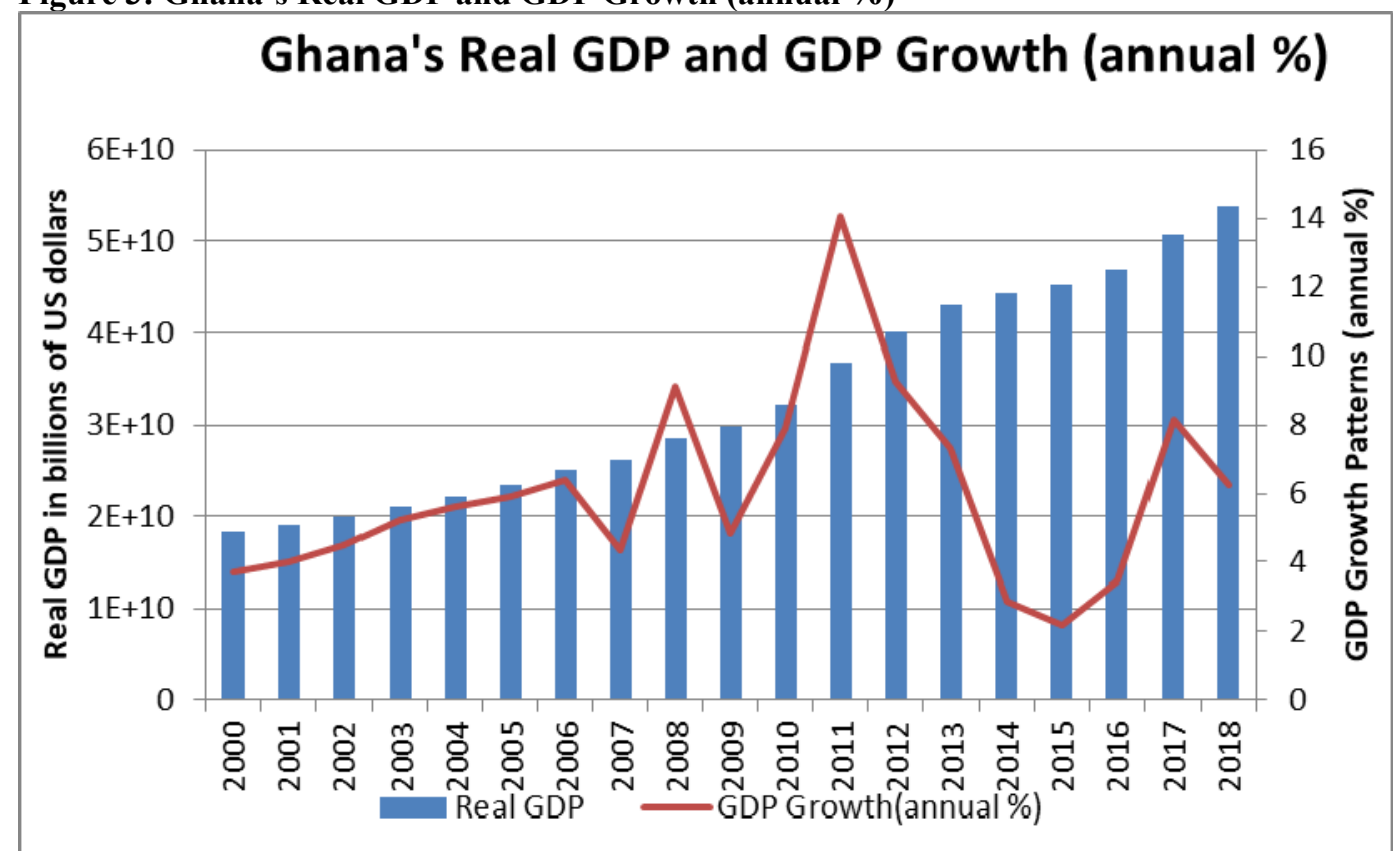

Source: Author's computation from World Development Indicators. World Bank (2020). Available: https://databank.worldbank.org/source/world-development-indicators

Ghana's Gross Domestic Product (GDP) has seen a steady growth over a long period of time, including the period between the year 2000 and 2018. Despite the fluctuations in GDP growth over the years, its impact has been positive, and therefore given a steady growth to real GDP in general. The appreciation in GDP growth could partly be attributed to the patterns of changes in the percentage share of oil rents accruing to the economy of Ghana. Comparing (figures 5 and 6) above, there is an indication of similarities in the patterns of GDP growth and oil rents, between the period of 2010 and 2017 with 2011 recording the highest GDP growth and oil rents share of GDP. This similarities between GDP growth patterns and oil rents share of GDP since 2010 could be 
attributed to the impact of oil rent on the economy of Ghana.

According to International Finance Corporation (IFC) (2018), GDP in Ghana grew at an annual average rate of 5.8 percent for the period between 1996 and 2016. And the contribution of the oil and gas fields to the economy is the main reason for higher than usual GDP growth in 2010 to 2014. The growth in 2016 dropped by 1.2 percent from 2015 , due to the damage to the turret bearing of the floating production storage and offloading vessel (FPSO) Kwame Nkrumah operating in the Jubilee field.

\subsection{Percentage share of Oil Rents and other Key Sectors of Ghana's Economy.}

Ghana was producing crude oil in smaller quantities until 2007 when Ghana discovered crude oil in large quantities. The discovery of crude oil in large quantities has since demonstrated an increase in oil rents share of GDP with the highest record in 2011.

Figure 7 below, indicates trend in sectorial contribution towards Ghana's GDP. Ghana began as an agrarian economy with more of its GDP coming from the agricultural sector, followed by service sector, the next being industrial sector and oil being the least. In the year 2006, the trend in sectorial contribution towards GDP assumes changes with the service sector taken the lead with a tremendous increase. Since then the agricultural sector began to shrink with fluctuations. Although, the industrial and oil sectors experience fluctuations, yet they fluctuate with increasing effect.

The increasing effect of oil sector of the economy is an indication of growth, just as in the case of service and industrial sectors. The paradigm shift in Ghana's economy from an agrarian to a more industrialized and service oriented economy with gradual increase in oil discoveries is an indication of growth and development. This can be confirmed by Lewis two-sector economy where labour is shifted from a primitive agricultural sector to a more industrialized economy, characterized by an increased production as a result of industrial investment and capital accumulation in the modern industrial sector (Todaro and Smith, 2012).

Figure 4: Percentage share of Oil Rents and other Key Sectors of Ghana's Economy

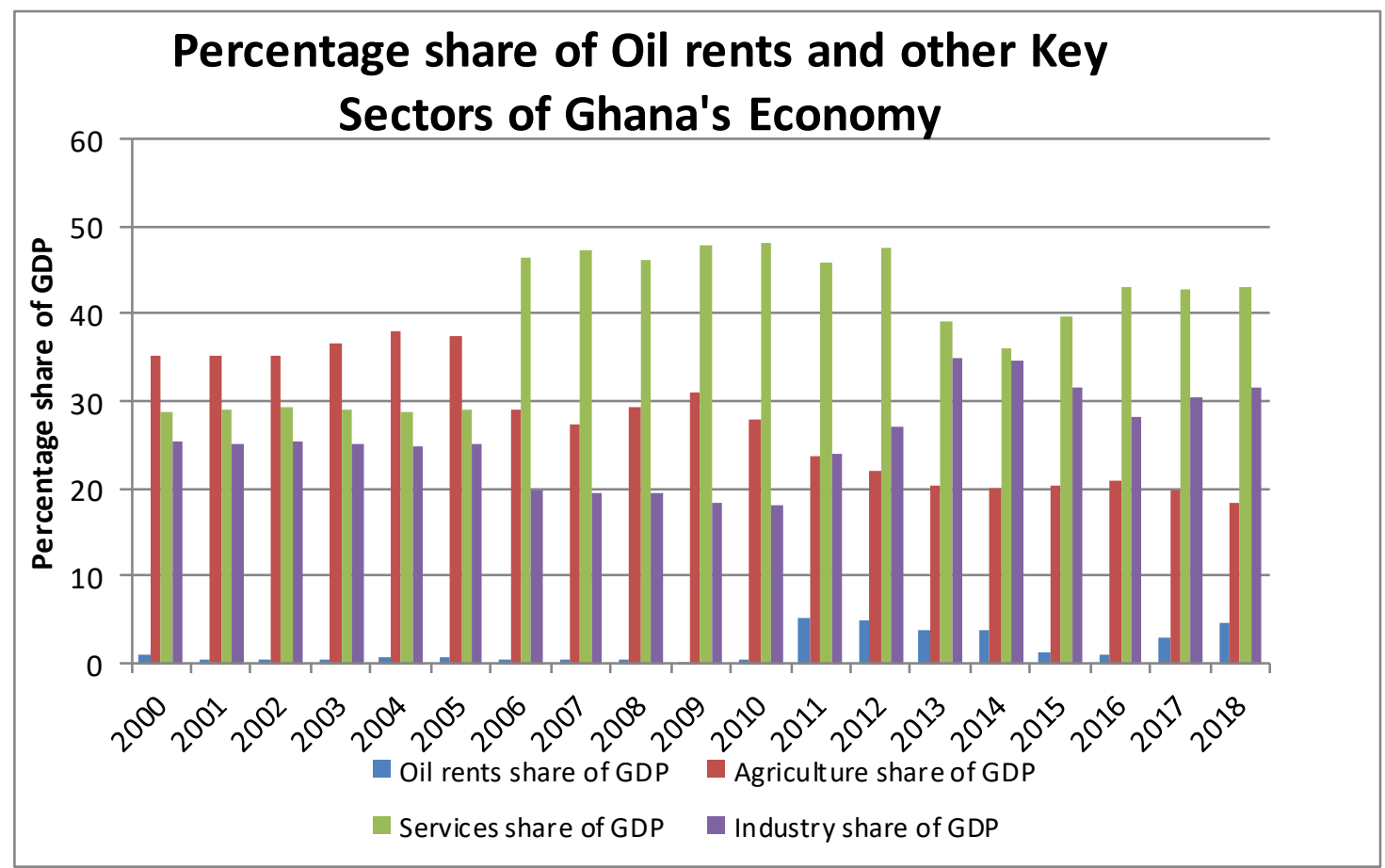

Source: Author's computation from World Development Indicators. World Bank (2020). Available: https://databank.worldbank.org/source/world-development-indicators

\subsection{The True State and Performance of Ghana's Oil and Gas Industry (2000-2018)}

It is notably clear that Norway and Nigeria has more oil reserves than Ghana and therefore it is expected that Norway and Nigeria would have more oil rents than Ghana. Worldometer, an oil and gas portal gave a list of proven oil reserves by country and their percentage share of world oil reserve. The list ranked Nigeria on $10^{\text {th }}$ position with proven oil reserve of $37,070,000,000$ and world share of $2.2 \%$; Norway was ranked on $22^{\text {nd }}$ position with proven oil reserve of $5,138,767,000$ and world share of $0.31 \%$; and Ghana was ranked on $43^{\text {rd }}$ position with proven oil reserve of $660,000,000$ and world share of $0.040 \%$.

Meanwhile, it is imperative to assess the patterns of oil rents among these three countries in order to 
determine the true state and performance of Ghana's oil and gas sector, since Norway is recognised as one of the successful oil-rich countries in the world and Nigeria being otherwise. The patterns in (figure 8) below are indications that since the production of oil in large quantities in the year 2010, Ghana has been performing well with its percentage share of oil rents towards its economy. Also, despite the fluctuations in oil rents among the three countries, Ghana continues to appreciate, considering the initial contribution in 2000 to its contribution in 2018 where Ghana's oil rent almost converge (catch-up) with that of Norway despite the disparities in oil reserves between the two countries. On the other hand, Norway continues to experience gradual declination and Nigeria continues to experience sharp declination in oil rents taken into considering their initial productions in 2000 to their contributions in 2018. The continuous appreciation in Ghana's oil rents could be attributed to its continues discovery and good management practices as confirmed by Civil Society Platform on Oil and Gas, Ghana (2011) whereas, the continuous declination in oil rents of Norway and Nigeria could be attributed to declination in oil reserves or otherwise. Figure 8 below, is a representation of patterns in oil rents among Ghana, Norway and Nigeria.

Figure 5: The True State and Performance of Ghana's Oil and Gas Industry (2000-2018)

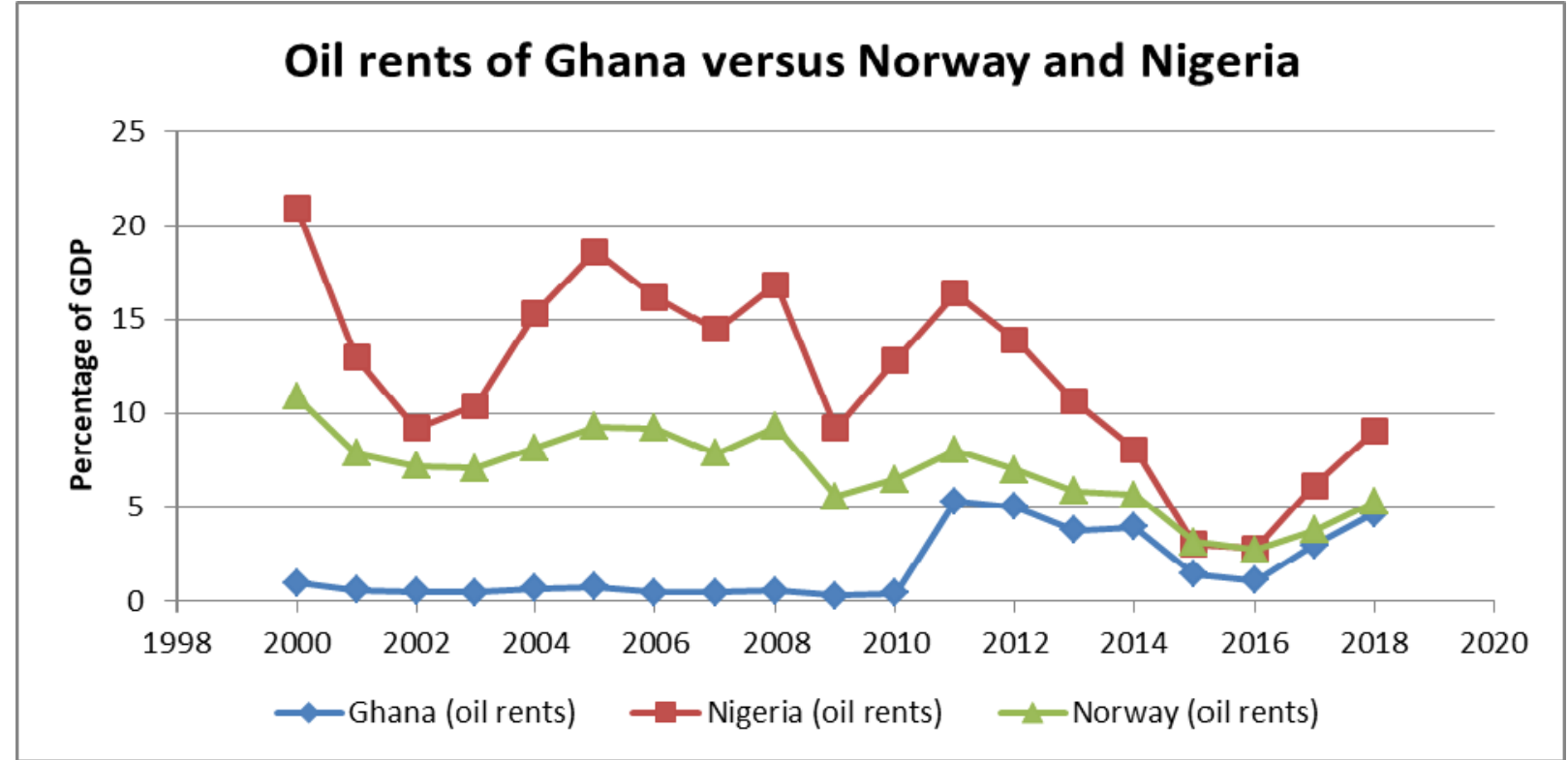

Source: Author's computation from World Development Indicators. World Bank (2020). Available: https://databank.worldbank.org/source/world-development-indicators

\subsection{Impact of Oil and Gas Production on the Economy of Ghana}

One of the objectives of this study is to assess the economic contribution of oil and gas production on Ghana's economy. In view of this, the following analyses were conducted to arrive at the said objective.

4.5.1 Descriptive Statistics

Before analyzing the model of simple linear regression and impact of oil rents on GDP growth of Ghana, the descriptive statistics of Ghana, Norway and Nigeria will be presented below for analysis.

Table 2: Descriptive Statistics of Oil Rents and GDP growth of Ghana (2000-2018)

\begin{tabular}{|l|l|l|l|l|l|}
\hline Variables & Observation & Minimum & Maximum & Mean & Std. Deviation \\
\hline GDP growth (annual \%) & 19 & 2.18 & 14.05 & 6.0584 & 2.81636 \\
\hline Oil rents (\% of GDP) & 19 & 0.28 & 5.31 & 1.7963 & 1.80643 \\
\hline
\end{tabular}

Source: Author's computation from World Development Indicators. World Bank (2020). Available: https://databank.worldbank.org/source/world-development-indicators

The (table 2) above shows the summary statistics of the variables used for the analysis of Ghana's oil and gas sector; these are the mean, maximum values, minimum values and the standard deviations. It shows that the minimum and the maximum GDP growth in Ghana between the period 2000 and 2018 were $2.18 \%$ and $14.05 \%$ respectively. Averagely, Ghana has been experiencing GDP growth of $6.1 \%$ per annum. Also, oil rents share of GDP had a minimum value of $0.28 \%$ and a maximum value of $5.31 \%$, with an average contribution of $1.8 \%$ per annum. 
Table 3: Descriptive Statistics of Oil Rents and GDP growth of Norway (2000-2018)

\begin{tabular}{|l|l|l|l|l|l|}
\hline Variables & Observation & Minimum & Maximum & Mean & Std. Deviation \\
\hline GDP growth (annual \%) & 19 & -1.73 & 3.97 & 1.7053 & 1.25964 \\
\hline Oil rents (\% of GDP) & 19 & 2.70 & 10.88 & 6.8458 & 2.18893 \\
\hline
\end{tabular}

Source: Author's computation from World Development Indicators. World Bank (2020). Available: https://databank.worldbank.org/source/world-development-indicators

The (table 3) above shows the summary statistics of the variables used for the analysis of Norway's oil and gas sector; these are the mean, maximum values, minimum values and the standard deviations. It shows that the minimum and the maximum GDP growth in Norway between the period 2000 and 2018 were $-1.73 \%$ and $3.97 \%$ respectively. Averagely, Norway has been experiencing GDP growth of $1.71 \%$ per annum. Also, oil rents share of GDP had a minimum value of $2.70 \%$ and a maximum value of $10.88 \%$, with an average contribution of $2.19 \%$ per annum.

Table 4: Descriptive Statistics of Oil Rents and GDP growth of Nigeria (2000-2018)

\begin{tabular}{|l|l|l|l|l|l|}
\hline Variables & Observation & Minimum & Maximum & Mean & Std. Deviation \\
\hline GDP growth (annual \%) & 19 & -1.62 & 15.33 & 5.8447 & 3.54566 \\
\hline Oil rents (\% of GDP) & 19 & 2.81 & 20.91 & 11.9321 & 5.00079 \\
\hline
\end{tabular}

Source: Author's computation from World Development Indicators. World Bank (2020). Available: https://databank.worldbank.org/source/world-development-indicators

The (table 4) above shows the summary statistics of the variables used for the analysis of Nigeria's oil and gas sector; these are the mean, maximum values, minimum values and the standard deviations. It shows that the minimum and the maximum GDP growth in Nigeria between the period 2000 and 2018 were $-1.62 \%$ and $15.33 \%$ respectively. Averagely, Nigeria has been experiencing GDP growth of 5.84\% per annum. Also, oil rents share of GDP had a minimum value of $2.81 \%$ and a maximum value of $20.91 \%$, with an average contribution of $11.93 \%$ per annum.

Ghana seems to have experienced a more steady growth with relatively little fluctuations in its percentage share of oil rents than Norway and Nigeria (2000-2018). Also, with reference to the deviations in the mean values of the three countries, Ghana experience's a more steady growth in its oil rents than Norway and Norway also experience's more steady growth than Nigeria.

\subsubsection{Impact of Oil Rents on GDP Growth of Ghana's Economy}

Ordinary Least Squares (OLS) regression, specifically, Simple Linear Regression was used to analyzed the impact of oil rents on the economy of Ghana. It was observed that oil rents (predictor variable) was significant at $0.05(5 \%)$ which is an indication of $95 \%$ level of confident the oil rents do affect the economy of Ghana. The (table 5) below shows the results of the regression analysis. It can be observed that oil rents had a positive impact on GDP growth, thereby impacting the economy of Ghana positively. The coefficient of oil rents (\% of GDP) was 0.788 , indicating that a percentage increase in oil rents will lead to a corresponding increase in GDP growth (annual \%) by $0.788 \%$ per annum. It is therefore obvious that under normal circumstance, increase in oil rents (ceteris paribus), will lead to a correspondent increase in GDP growth. Also, the $\mathrm{R}^{2}$ indicates that $25.6 \%$ of the variation in GDP growth was explained by oil rents share of GDP or it is as a result of oil rents contribution to GDP of Ghana.

Table 5: Regression Analysis representing impact of Oil Rents on GDP Growth of Ghana's Economy (2000-2018).

\begin{tabular}{|l|l|l|l|l|}
\hline Variables & Coefficient & Standard Error & $\boldsymbol{t}$-Statistics & $\boldsymbol{p}$-Value \\
\hline Constant & 4.643 & 0.820 & 5.661 & 0.000 \\
\hline Oil rents (\% of GDP) & 0.788 & 0.326 & 2.416 & 0.027 \\
\hline $\mathrm{R}^{2}$ & 0.256 & & & \\
\hline
\end{tabular}

Source: Author's computation from World Development Indicators. World Bank (2020). Available: https://databank.worldbank.org/source/world-development-indicators

\subsection{CONCLUSION}

The study has proven that revenue accruing from oil rents affect GDP growth positively and therefore considered impactful on Ghana's economy. Although, it contributions towards GDP growth (2000-2018) were not much significant, yet it is still an indication of growth since it represents net addition to capital stock.

The study further revealed general fluctuations in the contribution of oil rents to the Gross Domestic Product (GDP) of Ghana, with the highest record in 2011 and the least in 2009 between the period of 2000 and 2018. Despite the fluctuations in oil rents share of GDP over the years, there has also been a significant increase since 2011. The appreciations in oil rent since 2011 could be linked to the significant increase in crude oil production since the discovery of oil in large quantities in the year 2007 and good managerial practices.

Ghana's Gross Domestic Product (GDP) has seen a steady growth over a long period of time, including the 
period between 2000 and 2018. Despite the fluctuations in GDP growth over the years, its impact has been positive, and therefore given a steady growth to real GDP in general. The appreciation in GDP growth could partly be attributed to the patterns of changes in the percentage share of oil rents accruing to the economy of Ghana.

By conducting analysis on the key sectors of Ghana's economy, it was revealed that since the year 2006, the trends in sectorial contribution towards GDP have assumed changes with the service sector taken the lead, industry being second, the third being agriculture and with a good performance form the oil industry. The paradigm shift in Ghana's economy from an agrarian to a more industrialized and service oriented economy with gradual increase in oil discoveries is an indication of growth and development.

Ghana seems to have experienced a more steady growth with relatively little fluctuations in its percentage share of oil rents than Norway and Nigeria (2000-2018). Also, with reference to the deviations in the mean values of the three countries, Ghana experience's a more steady growth in its oil rents than Norway and Norway also experience's more steady growth than Nigeria.

Finally, the research further revealed that since the production of oil in large quantities in the year 2010, Ghana has been performing well with its percentage share of oil rent towards its economy. Despite the fluctuations in oil rents among the three countries, Ghana continues to increase, considering its initial contribution in 2000 to its contribution in 2018 where Ghana's oil rent almost converge (catch-up) with that of Norway irrespective of wide disparities in oil reserves between the two countries. On the other hand, Norway continues to experience gradual declination and Nigeria continues to experience sharp declination in oil rents taken into considering their initial productions in 2000 to their contributions in 2018.

\section{REFERENCES}

Acquah-Andoh, E., Gyeyir, D.M., Aanye, D.M. and Ifelebuegu, A. (2018) 'Oil and Gas Production and the Growth of Ghana's Economy: An Initial Assessment'. International Journal of Economics \& Financial Research. vol. 4, no. 10, pp. 303-312. Available online: https://pure.coventry.ac.uk/ws/portalfiles/portal/22206875/Binder2.pdf (Downloaded on 19 ${ }^{\mathrm{TH}}$ January, 2021, at 4:11PM)

Boohene, R. and Peprah J.A. (2011). Women, Livelihood and Oil and Gas Discovery in Ghana: An exploratory study of Cape Three Points and surrounding Communities. Journal of Sustainable Development. Vol. 4, No. 3; June 201. DOI:10.5539/jsd.v4n3p185.

Civil Society Platform on Oil and Gas - Ghana (2011). Ghana's Oil Boom: A Readiness Report Card. Available online: https://s3.amazonaws.com/oxfam-us/www/static/oa3/files/ghana-oil-readiness-report-card.pdf (Downloaded on $19^{\mathrm{TH}}$ January, 2021, at 4:21PM)

Dah, F.K. and Khadijah, M.S. (2010). The Contribution of Oil to the Economic Development of Ghana: The Role of Foreign Direct Investments (FDI) and Government Policies. A Master thesis in International Business. Department of Economics and Informatics University West. Available online: https://www.divaportal.org/smash/get/diva2:331510/FULLTEXT01.pdf (Downloaded on 19 ${ }^{\mathrm{TH}}$ January, 2021, at 4:10PM)

Darkwah, A. K. (2010). The Impact of Oil and Gas Discovery and Exploration Communities with Emphasis on Women. Available online: https:/genderandsecurity.org/sites/default/files/Darkwah_The Impact of oil gas discovery exploratn on communities .pdf (Downloaded on $23^{\text {rd }}$ January, $202 \overline{1}$, at $2: \overline{10} \mathrm{PM}$ )

Economics help (2021). Resource Curse. Helping to Simplify Economics. Available: https://www.economicshelp.org/blog/glossary/resource-curse/ (Accessed on $28^{\text {th }}$ January, 2021, at 1:10PM)

Fosu, A.K. (2017). Oil and Ghana's Economy. Research Gate. DOI: 10.1093/acprof:oso/9780198753438.003.0009 Available online: https://www.researchgate.net/publication/315601758_Oil_and_Ghana's_Economy/link/5b43516a458515f71 cb60d7d/download (Downloaded on 19 ${ }^{\mathrm{TH}}$ January, 2021, at 4:11PM)

Friedrich Ebert Stiftung Ghana (2011). Youth and Oil and Gas Governance in Ghana. Edited and Published by Friedrich-Ebert-Stiftung Ghana. Available online: http://library.fes.de/pdf-files/bueros/ghana/10509.pdf (Downloaded on $23^{\text {rd }}$ January, 2021, at 1:10PM)

Gary, Iva (2009). 'Ghana's Big Test: Oil's Challenge to Democratic Development' Oxfam America and Integrated Social Development Centre. Available online: https://csis-website-prod.s3.amazonaws.com/s3fspublic/legacy_files/files/attachments/090405_ghana_oil_powerpoint_dc.pdf (Downloaded on 23 $3^{\text {rd }}$ January, 2021, at 1:10PM)

Government.no (2020). Norway's Oil History in 5 minutes. Available online: https://www.regjeringen.no/en/topics/energy/oil-and-gas/norways-oil-history-in-5minutes/id440538/\#: :text=The\%20first\%20well\%20was\%20drilled,1966\%2C\%20but $\% 20 \mathrm{it} \% 20 \mathrm{was} \% 20 \mathrm{dr}$ y.\&text=With $\% 20$ the $\% 20$ Ekofisk $\% 20$ discovery $\% 20$ in,Norwegian $\% 20$ oil $\% 20$ adventure $\% 20$ really $\% 20$ bega n.\&text=Foreign $\% 20$ companies $\% 20$ dominated $\% 20$ exploration $\% 20$ off,first $\% 20$ oil $\% 20$ and $\% 20$ gas $\% 20$ field 
s. (Downloaded on $22^{\text {nd }}$ January, 2021, at 8:30PM)

International Finance Corporation (IFC). The Word Bank Group (2018). Estimating the Effects on Growth and Jobs of the Development of the Oil and Gas Sector in Ghana (2015-30): A Modeling and Value Chain Analysis. Available online: https:/www.commdev.org/pdf/publications/Estimating-OG-Effects-GhanaRev.-7-06-17-2018.pdf (Downloaded on 20 $0^{\text {th }}$ January, 2021, at 10:41AM)

Lucas, R. E. (1990). Why Doesn't Capital Flow from Rich to Poor Countries? The American Economic Review 80(2): 92-96. Available online: https:/www.nyu.edu/econ/user/debraj/Courses/Readings/LucasParadox.pdf (Downloaded on $11^{\text {th }}$ January, 2021, at 7:10PM)

Misini, S. (2017). The Effect of Economic Growth in Relation to Unemployment. Journal of Economics and Economic Education Research. Available online: https://www.researchgate.net/publication/333194679_THE_EFFECT_OF_ECONOMIC_GROWTH_IN_R ELATION_TO_UNEMPLOYMENT/link/5ce08f73458515712eb4b5a3/download (Downloaded on $\overline{1} 9^{\text {th }}$ January, 2021 , at 4:00PM)

Nigerian National Petroleum Corporation (NNPC) (2020). History of the Nigerian Petroleum Industry. Available online: https:/nnpcgroup.com/NNPC-Business/Business-Information/Pages/IndustryHistory.aspx\#: :text=\%E2\%80\%8BHistory $\% 20$ of $\% 20$ the $\% 20$ Nigerian,half $\% 20 \mathrm{a} \% 20$ century $\% 20$ of $\% 20$ ex ploration.\&text $=$ Following $\% 20$ the $\% 20$ discovery $\% 20$ of $\% 20$ crude,in $\% 20$ the $\% 20$ Eastern $\% 20$ Niger $\% 20$ Delta (Downloaded on $25^{\text {th }}$ January, 2021, at 8:30PM)

Norwegian Petroleum Directorate (2020). Norway's Petroleum History. Available online: https://www.norskpetroleum.no/en/framework/norways-petroleum-history/ (Downloaded on 22 ${ }^{\text {nd }}$ January, 2021 , at 8:30PM)

Okorobia, A.M. and Olali, S.T. (2018). Chapter 2 - The Historical Trajectory of Crude Oil Exploration and Production in Nigeria, 1930-2015. Science Direct. Available online: https://doi.org/10.1016/B978-0-12809399-3.00002-1 (Downloaded on 25th January, 2021, at 9:30PM)

Oxford Reference (2021). Resource Curse. Available online: https://www.oxfordreference.com/view/10.1093/acref/9780199599868.001.0001/acref-9780199599868-e1574 (Accessed on $27^{\text {th }}$ January, 2021, at 7:10PM)

Shamo, W. (2013). Oil and Gas Development in Ghana. Ministry of Energy and Petroleum.

The Law Reviews (2020). The Oil and Gas Law Review. Edition 8. Law Business Research. Published: November 2020. Available online: https://thelawreviews.co.uk/edition/the-oil-and-gas-law-review-edition8/1235025/ghana (Downloaded on 27 ${ }^{\text {th }}$ January, 2021, at 7:10PM)

Todaro M., Smith, S. (2012). Economic Development, Eleventh Edition. Boston (pp. 112-114). Available online: http://eco.eco.basu.ac.ir/BasuContentFiles/57/57304a77-1269-4081-bd5b-4c66b84b06a4.pdf (Downloaded on $11^{\text {th }}$ January, 2021, at $\left.6: 10 \mathrm{PM}\right)$

UK Essays. (November 2018). Discovery of Oil in Ghana Economics Essay. Available online: https://www.ukessays.com/essays/economics/discovery-of-oil-in-ghana-economics-essay.php?vref=1 (Downloaded on $23^{\text {rd }}$ January, 2021, at 8:10PM)

United Nations Conference on Trade and Development - UNCTAD, 2003. Investment Policy Review: Ghana. United Nations Conference on Trade and Development. Available online: https://unctad.org/system/files/official-document/iteipcmisc14rev1_en.pdf (Downloaded on 22 ${ }^{\text {nd }}$ February, 2021 , at 8:55PM)

World Bank (2020). World Development Indicators. Available online: https://databank.worldbank.org/source/world-development-indicators (Downloaded on 19 ${ }^{\text {th }}$ January, 2021, at $6: 10 \mathrm{PM})$

Worldometer. Oil Reserves by Country. Available online: https://www.worldometers.info/oil/oil-reserves-bycountry/ (Accessed on $4^{\text {th }}$ February, 2021, at 10:40 PM)

Yeboah Evans, 2018. "Foreign direct investment in Ghana: The distribution among the sectors and regions", International Journal of Current Research, 10, (01), 64292-64297. Available online: https://www.researchgate.net/publication/328859137_Foreign_Direct_Investment_In_Ghana_the_Distributi on_Among_the_Sectors_and_Regions/link/5bff991292851c63caafd9f $\bar{f} /$ download ${ }^{-}$(Downloaded on $22^{\text {nd }}$ February, 2021, at 8:50PM) 